\title{
Nitrogen Fertigation Rates Affect Stored Nitrogen, Growth, and Blooming in Iris germanica 'Immortality'
}

Xiaojie Zhao, Guihong Bi ${ }^{1}$, Richard L. Harkess, Jac J. Varco, and Tongyin $\mathbf{L i}$

Department of Plant and Soil Sciences, Mississippi State University, Mississippi State, MS 39762

Eugene K. Blythe

Coastal Research and Extension Center, Mississippi State University, South Mississippi Branch Experiment Station, Poplarville, MS 39470

Additional index words. tall bearded iris, reblooming, ${ }^{15} \mathrm{~N}$, nutrient use, nutrient partitioning

Abstract. Tall bearded (TB) iris (Iris germanica L.) has great potential as a specialty cut flower due to its fragrance and showy, multicolor display; however, limited research has been reported on optimal nitrogen $(N)$ nutrient management for TB iris. The objectives of this study were to investigate the effects of $N$ fertilizer rate on plant growth and flowering of 'Immortality' iris and determine the influence of both stored $\mathrm{N}$ and springapplied $N$ fertilizer on spring growth and flowering. On 14 Mar. 2012, rhizomes of 'Immortality' iris were potted in a commercial substrate with no starter fertilizer. Plants were fertigated with $0,5,10,15$, or 20 mм $\mathrm{N}$ from $\mathrm{NH}_{4} \mathrm{NO}_{3}$ twice per week from 28 Mar. to 28 Sept. 2012. In 2013, half of the plants from each of the $2012 \mathrm{~N}$ rate were supplied with either 0 or $10 \mathrm{~mm} \mathrm{~N}$ from ${ }^{15} \mathrm{NH}_{4}{ }^{15} \mathrm{NO}_{3}$ twice per week from 25 Mar. to 7 May 2013. Growth and flowering data including plant height, leaf SPAD, number of fans and inflorescence stems, and length of inflorescence stem were collected during the growing season. Plants were harvested in Dec. 2012 and May 2013 to measure dry weight and N concentration in leaves, roots, and rhizomes. Results showed higher $2012 \mathrm{~N}$ rates increased plant height, leaf SPAD reading, and number of inflorescence stems at first and second blooming in 2012. Greater $2012 \mathrm{~N}$ rates also increased plant dry weight and $\mathrm{N}$ content in all structures, and $\mathrm{N}$ concentration in roots and rhizomes. Rhizomes $\mathbf{5 8 . 8 \%}$ to $66.3 \%$ of total $N$ ) were the dominant sink for $N$ in Dec. 2012. Higher $2012 \mathrm{~N}$ rates increased plant height, number of fans, and the number of inflorescence stems at spring bloom in 2013. In May 2013, $N$ in leaf tissue constituted the majority $(51 \%$ to $64.3 \%)$ of the total plant $\mathrm{N}$. Higher $2012 \mathrm{~N}$ rates increased total dry weight, $\mathrm{N}$ concentration, and $\mathrm{N}$ content in all $2013{ }^{15} \mathrm{~N}$ rates; however, leaf dry weight in all plants was improved by 2013 ${ }^{15} \mathrm{~N}$ rate. Percentage of tissue $\mathrm{N}$ derived from $2013{ }^{15} \mathrm{~N}$ (NDFF) decreased with increasing $2012 \mathrm{~N}$ rate. New spring leaves were the dominant sink $(56.8 \%$ to $72.2 \%)$ for 2013 applied ${ }^{15} \mathrm{~N}$. In summary, 'Immortality' iris is capable of a second blooming in a growing season, this second blooming dependent on $\mathbf{N}$ fertilization rate in current year. A relatively high $\mathrm{N}$ rate is recommended to produce a second bloom.

Because of their showy, colorful flowers and sword-shaped leaves, TB iris (Iris germanica L.) has potential as a specialty cut

\footnotetext{
Received for publication 17 Nov. 2015. Accepted for publication 22 Dec. 2015.

Contribution of the Mississippi Agricultural and Forestry Experiment Station Journal article no. 12657. This work was supported by the Mississippi Agriculture and Forestry Experiment Station and the USDA National Institute of Food and Agriculture Hatch projects MIS-249120 and MIS-211090. Mention of a trademark, proprietary product, or vendor does not constitute a guarantee or warranty of the product by Mississippi State University and does not imply its approval to the exclusion of other products or vendors that also may be suitable. ${ }^{1}$ Corresponding author. E-mail: gbi@pss.msstate. edu.
}

flower. Tall bearded iris plants are composed of four parts: basal sword-shaped leaves (usually called fans), inflorescence stems, rhizomes, and roots. Reblooming or remontant irises (a subclass of I. germanica) are capable of blooming more than once per growing season. Use of reblooming iris for cut flower production has the potential to make TB iris cut flowers available over an extended season.

Nutrient management plays an important role in plant production. Nitrogen is one of the key macronutrients required for plant growth and development. Nitrogen combines with other elements to form amino acids used in building enzymes, chlorophyll, and other important compounds in plants (Marschner, 2012). Effective $\mathrm{N}$ management can reduce inputs and minimize $\mathrm{N}$ losses to the environment, but requires a thorough understanding of plant nutrient demand in terms of amount and timing (Lea-Cox et al., 2001; Syvertsen and Smith, 1996).

Determining optimal $\mathrm{N}$ application rate is important for optimizing plant growth and flowering. The optimal amount of $\mathrm{N}$ varies among plant species. When receiving 7.5 or $11.3 \mathrm{~mm} \mathrm{~N}$, anthurium (Anthurium andraeanum L.) produced more flowers than those receiving 5 or $15 \mathrm{~mm} \mathrm{~N}$ (Chang et al., 2012). The optimal $\mathrm{N}$ rate for maximal number of flower stems in peruvian lily (Alstroemeria L.) was $28.5 \mathrm{~mm}$ (Smith et al., 1998) and low N supply has negative effects on vegetative and reproductive growth. In tulip (Tulipa L.), insufficient $\mathrm{N}$ application resulted in a marked decrease in $\mathrm{N}$ concentration in daughter bulbs and floral differentiation was delayed if $\mathrm{N}$ concentration of planted bulbs was less than $0.6 \%$ to $0.7 \%$ (Baba and Ikarashi, 1967).

There exists a discrepancy in the recommended optimal amount of $\mathrm{N}$ for growth and flowering of TB iris. Most fertilizer recommendations for iris suggest using low $\mathrm{N}$ fertilizer rates, probably because high $\mathrm{N}$ rates can increase susceptibility to disease (Morris, 2011); however, some research has shown high $\mathrm{N}$ fertilizer rates increase the number of inflorescence stems and stem length of TB iris (Hanley et al., 2008). Lockatell and Spoon (2011) reported reblooming TB iris are heavy feeders and extra fertilizer during summer season could improve fall blooming; however, optimal $\mathrm{N}$ fertilizer rates to maximize economic production of this type of iris need to be determined.

Perennial species in general have the ability to build $\mathrm{N}$ reserves during progression to winter dormancy. In the rhizomatous plant siam tulip (Curcuma alismatifolia Gagnep.), $\mathrm{N}$ is mainly stored in rhizomes (Khuankaew et al., 2010; Ohtake et al., 2006). In a study by Ohyama et al. (1985), tulip plants stored nutrients in both scales and roots during the winter. Tall bearded iris has a thickened rhizome as storage tissue and spring growth and flowering production may be influenced by stored $\mathrm{N}$ from the previous year. In many plants, $\mathrm{N}$ reserves are remobilized during spring growth in support of early growth and development (Bi et al., 2003; Dong et al., 2004; Millard, 1995). In the woody tree pear (Prunus communis L.), both reserve and available soil $\mathrm{N}$ sources are important for spring growth (Cheng et al., 2001; Jordan et al., 2013).

A better understanding of how reblooming TB iris responds to fertilizer $\mathrm{N}$ rates and how plants use stored $\mathrm{N}$ in relation to springapplied $\mathrm{N}$ is needed to optimize growth and flowering and improve $\mathrm{N}$ fertilizer management. Therefore, the objectives of this study were to evaluate the effects of different $\mathrm{N}$ rates on plant growth and flowering of reblooming TB iris 'Immortality' and to determine the role of stored $\mathrm{N}$ on spring growth and uptake of spring-applied $\mathrm{N}$ fertilizer.

\section{Materials and Methods}

This study was conducted at Mississippi State University, Starkville, MS (lat. 33 $46^{\prime} \mathrm{N}$, 
long. $88^{\circ} 82^{\prime}$ W). On 14 Mar. 2012, rhizomes of 'Immortality' TB iris were field harvested, sorted for size (average caliper $=2.4 \mathrm{~cm}$ and length $=5.9 \mathrm{~cm}$ ), and potted with one rhizome per pot into $3.78-\mathrm{L}(23 \mathrm{~cm}$ diameter and $16 \mathrm{~cm}$ height) round plastic pots filled with a commercial substrate with no starter fertilizer (Fafard 2; Sun Gro Horticulture, Agawam, MA).

This experiment was a randomized complete block design with five blocks. In each block, 16 plant subsamples as a group were an experimental unit receiving one of five $\mathrm{N}$ rates. Fertigation was applied to plants twice per week from 28 Mar. to 28 Sept. 2012 with plants receiving $400 \mathrm{~mL}$ of modified Hoagland's solution (Hoagland and Arnon, 1950) containing one of five $\mathrm{N}$ rates $(0,5,10,15$, or $20 \mathrm{~mm} \mathrm{~N}$ from $\mathrm{NH}_{4} \mathrm{NO}_{3}$ ). $\mathrm{NH}_{4} \mathrm{NO}_{3}$ (Sigma Aldrich, St. Louis, MO) was the only source of $\mathrm{N}$. Other nutrients were from $\mathrm{N}$-free fertilizer $\left(1.06 \mathrm{mg} \cdot \mathrm{mL}^{-1}\right.$, Cornell No N Eq. 0-6-27; Greencare Fertilizers, Kankakee, IL). On 8 Dec. 2012, five plants (one from each block) from each $2012 \mathrm{~N}$ rate were randomly selected and destructively harvested.

Beginning on 25 Mar. 2013, 7 of the 15 plants that had received each $2012 \mathrm{~N}$ rate were fertigated twice per week for 6 weeks with $250 \mathrm{~mL}$ modified Hoagland's solution containing $10 \mathrm{~mm} \mathrm{~N}$ from ${ }^{15} \mathrm{NH}_{4}{ }^{15} \mathrm{NO}_{3}$. ${ }^{15} \mathrm{Nitrogen}-\mathrm{labeled}$ fertilizer was used to distinguish between stored and applied $\mathrm{N}$ and to quantify allocation of $\mathrm{N}$ within the plant. Another 7 of the 15 plants from $2012 \mathrm{~N}$ rates were fertigated with $250 \mathrm{~mL} \mathrm{~N}$-free modified Hoagland's solution (one plant of 15 remained unused in 2013). The resulting treatment design was a factorial of five $2012 \mathrm{~N}$ rates and two $2013{ }^{15} \mathrm{~N}$ rates. On 7 May 2013, five plants from each 2012 and 2013 fertigation combination were randomly selected and destructively harvested.

During the growing season, data for flowering (number of inflorescences stems and inflorescence stem length), plant height (average height of the three tallest fans), and SPAD reading (SPAD-502; Minolta Camera Co., Japan, one of the first two fully expended leaves was selected to measure SPAD reading) were collected. At harvest, plant height and number of fans were recorded. Each plant was divided into leaves, roots, and rhizomes. All samples were oven dried at $60{ }^{\circ} \mathrm{C}$ until constant weight, then dry weights were recorded by tissue type. All samples were ground to pass a 40mesh sieve (Wiley Mill; Thomas Scientific, Swedesboro, NJ).

For plants harvested in Dec. 2012, the total $\mathrm{N}$ was determined by the Kjeldahl method (Schuman et al., 1973) at the Soil Testing Laboratory of Mississippi State University. For plants harvested in May 2013, N concentration was determined by an elemental $\mathrm{C} / \mathrm{N}$ analyzer (Carlo Erba, Milan, Italy). Isotopic ${ }^{15} \mathrm{~N}$ atom percent was determined by an elemental $\mathrm{C} / \mathrm{N}$ analyzer coupled to an Isoprime mass spectrometer (Micromass, Beberly, MA). Nitrogen derived from the labeled fertilizer (NDFF) for each sampled plant tissue was calculated as described by Dong et al. (2004):

$$
\text { NDFF } \%=\left(\begin{array}{c}
\%{ }^{15} \mathrm{~N} \text { sample } \\
\frac{-\%{ }^{15} \mathrm{~N} \text { control }}{\%{ }^{15} \mathrm{~N} \text { fertilizer }} \\
-\%{ }^{15} \mathrm{~N} \text { natural } \\
\text { abundance }
\end{array}\right) \times 100
$$

Natural abundance $\%{ }^{15} \mathrm{~N}$ is considered equal to 0.3665 atom percent; $\%{ }^{15} \mathrm{~N}$ sample $=$ atom percent ${ }^{15} \mathrm{~N}$ in plant sample; $\%{ }^{15} \mathrm{~N}$ fertilizer $=$ atom percent ${ }^{15} \mathrm{~N}$ in fertilizer applied ( 2 atom percent); the mean abundance of $\%{ }^{15} \mathrm{~N}$ in the control plants $\left(0 \mathrm{~mm}{ }^{15} \mathrm{~N}\right.$ rate in 2013) was $0.3700,0.3753$, and 0.3862 atom percent for leaves, roots, and rhizomes, respectively. The amount of fertilizer ${ }^{15} \mathrm{~N}$ allocated to different tissue structures was calculated by multiplying NDFF\% by the $\mathrm{N}$ content of leaves, roots, and rhizomes. The amount of fertilizer ${ }^{15} \mathrm{~N}$ recovered by each plant was calculated as the sum of fertilizer ${ }^{15} \mathrm{~N}$ allocated to leaves, roots, and rhizomes. The $\mathrm{N}$ content of each structure was calculated by multiplying the dry mass by its $\mathrm{N}$ concentration. Total plant $\mathrm{N}$ content was calculated as the sum of the content in leaves, roots, and rhizomes. For iris plants that did not receive fertilizer $\mathrm{N}$ in Spring 2013, the total $\mathrm{N}$ content of the new leaves, roots, and rhizomes was considered the amount of reserve $\mathrm{N}$ remobilized from storage tissues to new growth. Nitrogen uptake efficiency during Spring 2013 was calculated as N in plants derived from fertilizer divided by amount of ${ }^{15} \mathrm{~N}$ fertilizer applied in 2013.

All data, except count data, were analyzed using either one-way analysis of variance (ANOVA) with $2012 \mathrm{~N}$ rate as a main effect (2012 data) or a two-way ANOVA with 2012 $\mathrm{N}$ rate and $2013{ }^{15} \mathrm{~N}$ treatment as main effects in a complete factorial design. Continuous response data were analyzed using linear models with the generalized linear model procedure of SAS (version 9.3; SAS Institute, Cary, NC) and count data (fans per plant, inflorescences per plant) were analyzed using generalized linear mixed models with the GLIMMIX procedure of SAS. Differences among $2012 \mathrm{~N}$ rate or main effects of $2012 \mathrm{~N}$ rate were compared using polynomial contrasts. Mean comparisons were made using Tukey's honestly significant difference $(P \leq$ $0.05)$

\section{Results}

Plant growth in May 2012 and flowering in 2012. In May 2012, increasing $2012 \mathrm{~N}$ rate generally increased plant height and leaf SPAD readings; however, plant height was little affected by $2012 \mathrm{~N}$ rates greater than 15 mM (Table 1). Increasing $2012 \mathrm{~N}$ rate generally increased number of inflorescences at first bloom in 2012, which was little affected by $2012 \mathrm{~N}$ rates greater than $10 \mathrm{~mm}$ (Table 2 ). All plants fertigated with $\mathrm{N}$ produced an inflorescence at first bloom; however, plants receiving 0 or $5 \mathrm{~mm} \mathrm{~N}$ did not produce any inflorescences at second bloom. At second blooming, $20 \mathrm{~mm}$ produced more inflorescence than 10 and $15 \mathrm{~mm}$. Stem length was similar among plants receiving different $2012 \mathrm{~N}$ rates at both first and second bloom (Table 2).

Dry weight, $N$ content, and concentration in Dec. 2012. Increasing $2012 \mathrm{~N}$ rate increased total plant dry weight and $\mathrm{N}$ content in Dec. 2012 (Tables 3 and 4). The effects of $2012 \mathrm{~N}$ rate on dry weight allocation and $\mathrm{N}$ status varied among structures (Tables 3 and 4). Increasing $2012 \mathrm{~N}$ rate increased dry weight allocation to leaves and decreased dry weight allocation to roots and rhizomes. In general, plants allocated a greater proportion of total dry weight to rhizomes in Dec. 2012 than leaves and roots. Regardless of the $2012 \mathrm{~N}$ rate, rhizomes and were the primary sink for $\mathrm{N}$ $(58.8 \%$ to $66.3 \%)$ in Dec. 2012 . With increasing $2012 \mathrm{~N}$ rate $\mathrm{N}$ concentration in roots showed quadratic trend. Greater $\mathrm{N}$ rate enhanced $\mathrm{N}$ concentration in rhizomes, which was little affected by $2012 \mathrm{~N}$ rates greater than $5 \mathrm{~mm}$. In contrast, greater $\mathrm{N}$ rate had little influence on the $\mathrm{N}$ concentration in leaves (Table 4).

Table 1. Plant height $(\mathrm{cm})$, leaf SPAD, and number of fans of container-grown 'Immortality' tall bearded iris. Plants were fertigated twice weekly with $0,5,10,15$, or $20 \mathrm{~mm}$ nitrogen (N) from Mar. to Sept. 2012 using a modified Hoagland's solution. Rhizomes were planted in Mar. 2012 and data were collected in May 2012 and Mar. 2013.

\begin{tabular}{|c|c|c|c|c|c|}
\hline \multirow[b]{2}{*}{$2012 \mathrm{~N}$ rate $(\mathrm{mm})$} & \multicolumn{2}{|c|}{ May 2012} & \multirow{2}{*}{$\frac{\text { Dec. } 2012}{\text { Fans/plant (no.) }}$} & \multicolumn{2}{|c|}{ Mar. 2013} \\
\hline & Plant $\mathrm{ht}^{\mathrm{z}}(\mathrm{cm})$ & Leaf SPAD & & Plant ht (cm) & Fans/plant (no.) \\
\hline 0 & $41 \mathrm{~d}^{\mathrm{y}}$ & $57 \mathrm{~d}$ & $3 \mathrm{~b}$ & $11 \mathrm{c}$ & $6 \mathrm{c}$ \\
\hline 5 & $47 \mathrm{c}$ & $64 \mathrm{c}$ & $5 \mathrm{ab}$ & $18 \mathrm{~b}$ & $11 \mathrm{bc}$ \\
\hline 10 & $52 \mathrm{~b}$ & $69 \mathrm{~b}$ & $6 \mathrm{ab}$ & $21 \mathrm{~b}$ & $15 \mathrm{ab}$ \\
\hline 15 & $54 \mathrm{ab}$ & $69 \mathrm{~b}$ & $6 \mathrm{ab}$ & $23 \mathrm{~b}$ & $13 \mathrm{ab}$ \\
\hline 20 & $56 \mathrm{a}$ & $73 \mathrm{a}$ & $8 \mathrm{a}$ & $30 \mathrm{a}$ & $17 \mathrm{a}$ \\
\hline \multicolumn{6}{|l|}{ Contrasts $^{\mathrm{x}}$} \\
\hline $\mathrm{L}$ & $* * * *$ & $* * * *$ & $* *$ & $* * * *$ & $* * * * *$ \\
\hline Q & NS & $* *$ & NS & $*$ & NS \\
\hline
\end{tabular}

zPlant height was the average height of the three tallest fans.

y Means within a column followed by different letters denote significant differences (Tukey's honestly significant difference; $P \leq 0.05)$.

${ }^{\mathrm{x}}$ Significant linear (L) or quadratic (Q) trends at not significant (NS) or $P \leq 0.05(*), 0.01(* *), 0.001(* * *)$, $0.0001(* * * *)$. 
Table 2. Number and length $(\mathrm{cm})$ of blooming stalks of container-grown 'Immortality' tall bearded iris. Plants fertigated twice weekly with 0, 5, 10, 15, or 20 mm nitrogen (N) from Mar. to Sept. 2012 using a modified Hoagland's solution. Rhizomes were planted in Mar. 2012 and data were collected during the first blooming in spring and second blooming in Fall 2012.

\begin{tabular}{|c|c|c|c|c|}
\hline \multirow[b]{2}{*}{$2012 \mathrm{~N}$ rate $(\mathrm{mm})$} & \multicolumn{2}{|c|}{ 2012, First blooming } & \multicolumn{2}{|c|}{ 2012, Second blooming } \\
\hline & $\begin{array}{c}\text { Inflorescence/ } \\
\text { plant (no.) }\end{array}$ & $\begin{array}{l}\text { Stem length } \\
(\mathrm{cm})\end{array}$ & $\begin{array}{c}\text { Inflorescence/ } \\
\text { plant (no.) }\end{array}$ & $\begin{array}{c}\text { Stem length } \\
(\mathrm{cm})\end{array}$ \\
\hline 0 & $0.03 \mathrm{c}^{\mathrm{z}}$ & $34.0 \mathrm{~b}$ & $0.00 \mathrm{~b}$ & - \\
\hline 5 & $0.75 \mathrm{~b}$ & $37.4 \mathrm{~b}$ & $0.00 \mathrm{~b}$ & - \\
\hline 10 & $0.95 \mathrm{ab}$ & $39.0 \mathrm{ab}$ & $0.06 \mathrm{~b}$ & 49.0 \\
\hline 15 & $1.20 \mathrm{a}$ & $40.4 \mathrm{ab}$ & $0.11 \mathrm{~b}$ & 46.0 \\
\hline 20 & $1.30 \mathrm{a}$ & $45.1 \mathrm{a}$ & $0.34 \mathrm{a}$ & 45.7 \\
\hline \multicolumn{5}{|l|}{ Contrasts $^{\mathrm{y}}$} \\
\hline $\mathrm{L}$ & $* * * *$ & NS & NS & NS \\
\hline Q & $* * * *$ & NS & NS & NS \\
\hline
\end{tabular}

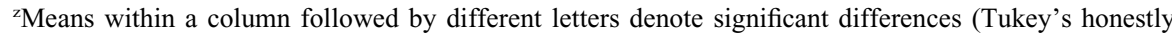
significant difference; $P \leq 0.05)$.

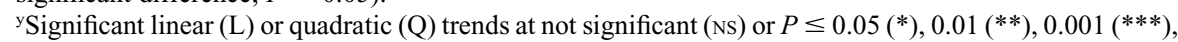
$0.0001(* * * *)$.

In 2012, first blooming happen from late June to middle July and second blooming happened from late August to middle October.

Table 3. Dry weight and dry weight allocation in tissues of container-grown 'Immortality' tall bearded iris. Plants were fertigated twice weekly with $0,5,10,15$, or $20 \mathrm{~mm}$ nitrogen (N) from Mar. to Sept. 2012 using a modified Hoagland's solution. Rhizomes were planted in Mar. 2012 and plants were harvested in Dec. 2012.

\begin{tabular}{|c|c|c|c|c|c|c|c|}
\hline \multirow[b]{2}{*}{$2012 \mathrm{~N}$ rate $(\mathrm{mm})$} & \multicolumn{4}{|c|}{ Dry wt (g) } & \multicolumn{3}{|c|}{ Dry wt allocation $(\%)$} \\
\hline & Leaf & Rhizome & Root & Total & Leaf & Rhizome & Root \\
\hline 0 & $3.4 \mathrm{c}^{\mathrm{z}}$ & $18.2 \mathrm{~b}$ & $3.0 \mathrm{~b}$ & $24.6 \mathrm{~b}$ & $13.9 \mathrm{c}$ & $73.9 \mathrm{a}$ & $12.2 \mathrm{c}$ \\
\hline 5 & $14.5 \mathrm{~b}$ & $28.7 \mathrm{ab}$ & $15.8 \mathrm{a}$ & $59.0 \mathrm{a}$ & $24.6 \mathrm{~b}$ & $48.8 \mathrm{~b}$ & $26.6 \mathrm{a}$ \\
\hline 10 & $20.2 \mathrm{ab}$ & $30.7 \mathrm{a}$ & $14.4 \mathrm{a}$ & $65.2 \mathrm{a}$ & $30.9 \mathrm{ab}$ & $47.1 \mathrm{~b}$ & $22.0 \mathrm{ab}$ \\
\hline 15 & $20.1 \mathrm{ab}$ & $30.4 \mathrm{a}$ & $14.8 \mathrm{a}$ & $65.2 \mathrm{a}$ & $31.1 \mathrm{ab}$ & $46.2 \mathrm{~b}$ & $22.7 \mathrm{ab}$ \\
\hline 20 & $25.2 \mathrm{a}$ & $32.1 \mathrm{a}$ & $13.4 \mathrm{a}$ & $70.7 \mathrm{a}$ & $36.1 \mathrm{a}$ & $44.7 \mathrm{~b}$ & $19.2 \mathrm{~b}$ \\
\hline \multicolumn{8}{|l|}{ Contrasts $^{y}$} \\
\hline $\mathrm{L}$ & $* * * *$ & $*$ & $* * * *$ & $* * * *$ & $* * * *$ & $* * * *$ & $* *$ \\
\hline Q & $* * * *$ & * & $* * * *$ & $* * * *$ & NS & $* * * *$ & $* * * *$ \\
\hline
\end{tabular}

${ }^{\mathrm{z}}$ Means within a column followed by different letters denote significant differences (Tukey's honestly significant difference; $P \leq 0.05)$.

${ }^{\mathrm{y}}$ Significant linear (L) or quadratic (Q) trends at not significant (NS) or $P \leq 0.05(*), 0.01(* *), 0.001(* * *)$, $0.0001(* * * *)$.

Table 4. Nitrogen (N) concentration and content of container-grown 'Immortality' tall bearded iris. Plants were fertigated twice weekly with $0,5,10,15$, or $20 \mathrm{~mm} \mathrm{~N}$ from Mar. to Sept. 2012 using a modified Hoagland's solution. Rhizomes were planted in Mar. 2012 and plants were harvested in Dec. 2012.

\begin{tabular}{|c|c|c|c|c|c|c|c|}
\hline \multirow[b]{2}{*}{$2012 \mathrm{~N}$ rate $(\mathrm{mM})$} & \multicolumn{3}{|c|}{$\mathrm{N}$ concn $(\%)$} & \multicolumn{4}{|c|}{$\mathrm{N}$ content (g/plant) } \\
\hline & Leaf & Rhizome & Root & Leaf & Rhizome & Root & Total \\
\hline 0 & $2.7 \mathrm{a}^{\mathrm{z}}$ & $1.3 \mathrm{~b}$ & $0.7 \mathrm{~b}$ & $0.09 \mathrm{c}$ & $0.24 \mathrm{~b}$ & $0.02 \mathrm{~b}$ & $0.35 \mathrm{c}$ \\
\hline 5 & $2.6 \mathrm{a}$ & $2.3 \mathrm{ab}$ & $0.7 \mathrm{~b}$ & $0.36 \mathrm{~b}$ & $0.60 \mathrm{ab}$ & $0.11 \mathrm{a}$ & $1.10 \mathrm{~b}$ \\
\hline 10 & $2.6 \mathrm{a}$ & $3.4 \mathrm{a}$ & $0.8 \mathrm{a}$ & $0.51 \mathrm{~b}$ & $1.10 \mathrm{a}$ & $0.12 \mathrm{a}$ & $1.70 \mathrm{ab}$ \\
\hline 15 & $2.6 \mathrm{a}$ & $3.4 \mathrm{a}$ & $1.1 \mathrm{a}$ & $0.51 \mathrm{~b}$ & $1.00 \mathrm{a}$ & $0.16 \mathrm{a}$ & $1.70 \mathrm{ab}$ \\
\hline 20 & $2.8 \mathrm{a}$ & $3.3 \mathrm{a}$ & $1.1 \mathrm{a}$ & $0.65 \mathrm{a}$ & $1.10 \mathrm{a}$ & $0.15 \mathrm{a}$ & $1.90 \mathrm{a}$ \\
\hline \multicolumn{8}{|l|}{ Contrasts $^{\mathrm{y}}$} \\
\hline $\mathrm{L}$ & NS & $*$ & NS & $* * * *$ & $*$ & $* * *$ & $* *$ \\
\hline Q & NS & $* * * *$ & $* * * *$ & $* * * *$ & $* * * *$ & $* * * *$ & $* * * *$ \\
\hline
\end{tabular}

${ }^{\mathrm{z}}$ Means within a column followed by different letters denote significant differences (Tukey's honestly significant difference; $P \leq 0.05)$.

${ }^{\mathrm{y}}$ Significant linear (L) or quadratic (Q) trends at not significant (NS) or $P \leq 0.05(*), 0.01(* *), 0.001(* * *)$, $0.0001(* * * *)$.

Plant growth in Mar. 2013. In Mar. 2013, before spring fertigation, plant height and number of new fans increased with increasing $2012 \mathrm{~N}$ rate. Plants receiving $20 \mathrm{~mm} \mathrm{~N}$ in 2012 had almost 3 -fold more fans and were almost three times taller than those receiving 0 mm N (Table 1).

Plant growth in May 2013. In May 2013, plant height was influenced by the
Both greater $2012 \mathrm{~N}$ rates and $2013{ }^{15} \mathrm{~N}$ rates increased leaf SPAD readings in May 2013 (Table 5).

Plant flowering in 2013. Number of inflorescence stems at first blooming in 2013 was influenced by the interaction of $2012 \mathrm{~N}$ rate and $2013{ }^{15} \mathrm{~N}$ rate (Table 5). In general, number of inflorescence at first bloom in 2013 increased with increasing $2012 \mathrm{~N}$ rate and $2013 \mathrm{~N}$ treatment had little influence on the number of inflorescences. Inflorescence stem length was unaffected by $2012 \mathrm{~N}$ rate or $2013{ }^{15} \mathrm{~N}$ rate (Table 5).

Dry weight, $N$ content, and concentration in May 2013. In May 2013 (after first bloom in 2013), increasing $2012 \mathrm{~N}$ rate increased dry weight and $\mathrm{N}$ content in all tissues (Tables 5 and 6). Spring $2013{ }^{15} \mathrm{~N}$ application increased dry weight in leaves, $\mathrm{N}$ content in rhizomes, and total $\mathrm{N}$ content. Regardless of treatments, allocation of dry weight and $\mathrm{N}$ content were greatest to the leaves, followed by rhizomes and roots (Tables 5 and 6). Leaves were the primary $\mathrm{N}$ sink in May 2013. Increasing $2012 \mathrm{~N}$ rate increased N concentration in rhizomes and roots. 2013 ${ }^{15} \mathrm{~N}$ application only enhanced $\mathrm{N}$ concentration in rhizomes (Table 6).

Spring uptake and allocation of ${ }^{15} \mathrm{~N}$ from fertilizer applied in 2013. In May 2013, the amount of recovered ${ }^{15} \mathrm{~N}$ in leaves and total plant tissue was similar across the $2012 \mathrm{~N}$ rates; however, the proportion of ${ }^{15} \mathrm{~N}$ in leaves, roots, and rhizomes derived from ${ }^{15} \mathrm{NH}_{4}{ }^{15} \mathrm{NO}_{3}$ fertilizer (NDFF\%) decreased as the $2012 \mathrm{~N}$ rate increased (Table 7). In addition, considering the same amount of ${ }^{15} \mathrm{~N}$ (10 mM) was applied across the $2012 \mathrm{~N}$ rates and a similar amount of ${ }^{15} \mathrm{~N}$ was taken up, $\mathrm{N}$ uptake efficiency (ratio of ${ }^{15} \mathrm{~N}$ uptake to ${ }^{15} \mathrm{~N}$ applied) in the spring growing season of 2013 was unaffected by $2012 \mathrm{~N}$ rate.

With the various $2012 \mathrm{~N}$ and $2013{ }^{15} \mathrm{~N}$ treatment combinations, ${ }^{15} \mathrm{~N}$ allocation followed a similar pattern to $\mathrm{N}$ allocation with leaves as the primary sink followed by rhizomes and roots (Table 7). The allocation of ${ }^{15} \mathrm{~N}$ to the leaves ( $57 \%$ to $72 \%$ ) confirms new leaves were the dominant sink for $\mathrm{N}$ uptake in Spring 2013.

\section{Discussion}

In May 2012, greater $2012 \mathrm{~N}$ rates led to more vigorous growth of 'Immortality' TB iris. These results are consistent with those reported for gladiolus (Gladiolus L.) (Khan et al., 2012) and dahlia (Dahlia Cav.) (Younis et al., 2009) of which the height of plants was improved by higher $\mathrm{N}$ fertilizer rates. Increasing $2012 \mathrm{~N}$ rate increased leaf SPAD readings in May 2012, which indicates $\mathrm{N}$ concentration in leaves was increased by increasing $2012 \mathrm{~N}$ rate. In agricultural production, fertilizer $\mathrm{N}$ is a major input and plant tissue $\mathrm{N}$ concentrations have been closely correlated with leaf SPAD reading in various crops (Gáborčík, 2003; Islam et al., 2009; Yasumoto et al., 2011). Leaf SPAD reading can be used as a preliminary diagnostic tool for efficient $\mathrm{N}$ management based on plant $\mathrm{N}$ 
Table 5. Growth and flowering data, dry weight, and dry weight allocation in tissues of container-grown 'Immortality' tall bearded iris in 2013. Plants were fertigated twice weekly with 0, 5, 10, 15, or 20 mm nitrogen (N) from Mar. to Sept. 2012 and twice weekly with 0 or 10 mm ${ }^{15} \mathrm{~N}$ from Mar. to May 2013 using a modified Hoagland's solution. Rhizomes were planted in Mar. 2012, plants were harvested in May 2013, flowering data collected during first bloom season in 2013 and growth data were collected in May 2013.

\begin{tabular}{|c|c|c|c|c|c|c|c|c|c|c|c|c|}
\hline \multirow[b]{3}{*}{$2013{ }^{15} \mathrm{~N}$ rate $(\mathrm{mm})$} & \multirow{3}{*}{$\begin{array}{c}2012 \mathrm{~N} \\
\text { rate }(\mathrm{mM})\end{array}$} & \multicolumn{4}{|c|}{ Growth and flowering data in 2013} & \multirow{2}{*}{\multicolumn{4}{|c|}{ Dry wt $(g)$}} & \multirow{2}{*}{\multicolumn{3}{|c|}{ Dry wt allocation (\%) }} \\
\hline & & \multirow{2}{*}{$\begin{array}{l}\text { Plant ht } \\
(\mathrm{cm})\end{array}$} & \multirow{2}{*}{$\begin{array}{c}\text { Fans/plant } \\
\text { (no.) }\end{array}$} & \multirow[b]{2}{*}{ SPAD } & \multirow{2}{*}{$\begin{array}{c}\text { Inflorescence/ } \\
\text { plant (no.) }\end{array}$} & & & & & & & \\
\hline & & & & & & Leaf & Rhizome & Root & Total & Leaf & Rhizome & Root \\
\hline \multirow[t]{8}{*}{0} & 0 & $41 \mathrm{e}^{\mathrm{z}}$ & & & $0 \mathrm{~d}$ & & & & & & & $25.0 \mathrm{a}$ \\
\hline & 5 & $58 \mathrm{~cd}$ & & & $0.2 \mathrm{~cd}$ & & & & & & & $16.4 \mathrm{bc}$ \\
\hline & 10 & $65 \mathrm{ab}$ & & & $0.33 \mathrm{bcd}$ & & & & & & & $13.6 \mathrm{bc}$ \\
\hline & 15 & $61 \mathrm{bc}$ & & & $0.47 \mathrm{a}-\mathrm{d}$ & & & & & & & $11.6 \mathrm{c}$ \\
\hline & 20 & $68 \mathrm{a}$ & & & $0.67 \mathrm{abc}$ & & & & & & & $11.0 \mathrm{c}$ \\
\hline & Contrasts $^{\mathrm{y}}$ & & & & & & & & & & & \\
\hline & $\mathrm{L}$ & $* * * *$ & & & $* * * *$ & & & & & & & $* *$ \\
\hline & Q & $* * *$ & & & NS & & & & & & & NS \\
\hline \multirow[t]{8}{*}{10} & 0 & $52 \mathrm{~d}$ & & & $0.27 \mathrm{bcd}$ & & & & & & & $18.6 \mathrm{~b}$ \\
\hline & 5 & $61 \mathrm{bc}$ & & & $0.13 \mathrm{~d}$ & & & & & & & $15.0 \mathrm{bc}$ \\
\hline & 10 & $63 \mathrm{abc}$ & & & $0.73 \mathrm{ab}$ & & & & & & & $12.1 \mathrm{c}$ \\
\hline & 15 & $65 \mathrm{ab}$ & & & $0.27 \mathrm{bcd}$ & & & & & & & $12.4 \mathrm{c}$ \\
\hline & 20 & $67 \mathrm{ab}$ & & & $0.87 \mathrm{a}$ & & & & & & & $11.8 \mathrm{c}$ \\
\hline & Contrasts & & & & & & & & & & & \\
\hline & $\mathrm{L}$ & $* * * *$ & & & $* * *$ & & & & & & & $* *$ \\
\hline & $\mathrm{Q}$ & NS & & & NS & & & & & & & ** \\
\hline \multicolumn{13}{|c|}{ Main effects of $2012 \mathrm{~N}$ rate } \\
\hline & 0 & & $6.4 \mathrm{~b}$ & $58.6 \mathrm{~b}$ & & $27.4 \mathrm{~d}$ & $30.5 \mathrm{c}$ & $15.9 \mathrm{ab}$ & $73.8 \mathrm{c}$ & $36.3 \mathrm{~b}$ & & \\
\hline & 5 & & $8.8 \mathrm{~b}$ & $58.8 \mathrm{~b}$ & & $41.5 \mathrm{c}$ & $44.5 \mathrm{bc}$ & $15.7 \mathrm{ab}$ & $101.7 \mathrm{~b}$ & $41.1 \mathrm{ab}$ & & \\
\hline & 10 & & $10.9 \mathrm{ab}$ & $61.3 \mathrm{ab}$ & & $46.5 \mathrm{bc}$ & $45.0 \mathrm{~b}$ & $13.9 \mathrm{~b}$ & $110.4 \mathrm{~b}$ & $41.9 \mathrm{ab}$ & & \\
\hline & 15 & & $10.8 \mathrm{ab}$ & $60.1 \mathrm{ab}$ & & $52.7 \mathrm{~b}$ & $55.6 \mathrm{ab}$ & $14.0 \mathrm{~b}$ & $122.2 \mathrm{~b}$ & $44.1 \mathrm{a}$ & & \\
\hline & 20 & & $13.9 \mathrm{a}$ & $63.0 \mathrm{a}$ & & $64.8 \mathrm{a}$ & $72.8 \mathrm{a}$ & $17.5 \mathrm{a}$ & $155.2 \mathrm{a}$ & $42.0 \mathrm{ab}$ & & \\
\hline & Contrasts & & & & & & & & & & & \\
\hline & $\mathrm{L}$ & & $*$ & & & $* * * *$ & $* * * *$ & NS & $* * * *$ & $*$ & & \\
\hline & $\mathrm{Q}$ & & NS & & & NS & NS & $* *$ & NS & NS & & \\
\hline \multicolumn{13}{|c|}{ Main effects of $2013{ }^{15} \mathrm{~N}$ rate } \\
\hline 0 & & & & $58.5 \mathrm{~b}$ & & $41.5 \mathrm{~b}$ & & & & $37.8 \mathrm{~b}$ & $46.7 \mathrm{a}$ & \\
\hline 10 & & & & $62.2 \mathrm{a}$ & & $51.6 \mathrm{a}$ & & & & $44.3 \mathrm{a}$ & $41.7 \mathrm{~b}$ & \\
\hline
\end{tabular}

${ }^{\mathrm{z}}$ Means within a column followed by different letters denote significant differences (Tukey's honestly significant difference; $P \leq 0.05$ ).

${ }^{y}$ Significant linear $(\mathrm{L})$ or quadratic $(\mathrm{Q})$ trends at not significant (NS) or $P \leq 0.05(*), 0.01(* *), 0.001(* * *), 0.0001(* * * *)$.

status (Ghosh et al., 2013; Netton et al., 2005).

Only plants receiving 10,15 , or $20 \mathrm{~mm} \mathrm{~N}$ in 2012 flowered in the Fall 2012. Flowering and reproductive growth require additional energy and nutrients. In dendrobium (Dendrobium nobile Lindl.), greater $\mathrm{N}$ fertilizer rate increased the number of flowers (Bichsel et al., 2008). Thus, a relatively high $\mathrm{N}$ rate may be necessary to produce a second bloom in late summer or fall (Lockatell and Spoon, 2011).

Nitrogen is one of the primary factors affecting vegetative growth. In this study, dry weight in Dec. 2012 had a positive relation with $2012 \mathrm{~N}$ rate, which is consistent with studies on 'Casa Blanca' lily (Lilium L.) and the rhizomatous plants ginger (Globba rosae L.) and siam tulip (Ruamrungsri et al., 2005, 2007; Zhu et al., 2012).

Plants receiving the $0 \mathrm{~mm} 2012 \mathrm{~N}$ rate had a lower proportion of dry weight allocated to roots than other $2012 \mathrm{~N}$ rates, which is contrary to common belief that under insufficient $\mathrm{N}$ supply plants tend to develop a larger root system to take up enough nutrients (Bi et al., 2007). One explanation could be that plants receiving $0 \mathrm{~mm} \mathrm{~N}$ may not have received enough nutrients to support basic root growth.

Nitrogen concentration in leaves was unaffected by $2012 \mathrm{~N}$ rate in Dec. 2012 and both
$2012 \mathrm{~N}$ rate and $2013{ }^{15} \mathrm{~N}$ rate in May 2013. Considering leaf dry weight of plants decreased with decreasing N rates, 'Immortality' TB iris plants may control leaf growth while maintaining optimal leaf $\mathrm{N}$ concentration under low $\mathrm{N}$ rates. This interpretation is supported by Lemaire and Millard (1999) who reported there was a trade-off between leaf growth and leaf $\mathrm{N}$ concentration in plants under restricted $\mathrm{N}$ supply.

In this study, $\mathrm{N}$ content in plants was increased by $\mathrm{N}$ supply in 2012 and 2013 . This result is consistent with studies of other geophyte species. For example, in lily (Lilium davidii Duch. ex Elwes), $\mathrm{N}$ accumulation was increased with increasing amount of $\mathrm{N}$ fertilizer (Lin et al., 2011). In cape cowslip (Lachenalia Jacq.), $\mathrm{N}$ supply increased $\mathrm{N}$ content in leaves and bulbs, and $\mathrm{N}$ content in leaves was higher than bulbs (Roodbol et al., 2002).

Regardless of 2012 N rate, in Dec. 2012 more than half of total $\mathrm{N}$ was allocated to rhizomes, which indicates the rhizome is a major $\mathrm{N}$ storage organ in winter. The capacity for storing $\mathrm{N}$ in rhizomes could increase the residence time of $\mathrm{N}$ in plants as the leaves dieback in winter and allow plants to grow when external resources are limiting. Storage organs store nutrients to maintain the viability of plants through unfavorable environmental periods.
With increasing $2012 \mathrm{~N}$ rate, a greater amount of $\mathrm{N}$ stored in rhizomes also indicates capacity for storing $\mathrm{N}$ in rhizomes, which may allow plants to accumulate more $\mathrm{N}$ than needed when the $\mathrm{N}$ supply exceeds demand for growth. This opinion is supported by results of other studies of rhizomatous plant. In siam tulip, the rhizome is the principal organ for $\mathrm{N}$ storage (Khuankaew et al., 2010; Ohtake et al., 2006). Tulips store nutrients in both scales and roots (Ohyama et al., 1985, 1988).

In Mar. 2013, increasing $2012 \mathrm{~N}$ rate increased both plant height and number of fans. Higher $2012 \mathrm{~N}$ rates produced larger iris plants in early Spring 2013, which indicates early spring growth of TB iris relies on $\mathrm{N}$ application in the previous year. In plants receiving higher $2012 \mathrm{~N}$ rates, a greater amount of $\mathrm{N}$ was stored in the rhizome, which satisfied the $\mathrm{N}$ requirement for early spring growth. Greater $2012 \mathrm{~N}$ rates led to an increased number of axillary rhizomes (each new fan develops an axillary rhizome), which may be beneficial for propagation; however, large numbers of axillary rhizomes may limit flower production due to reduced rhizome size.

In Spring 2013, ${ }^{15} \mathrm{~N}$ rate had little influence on the number of inflorescence. The previous season's fertilization and plant growth are important for production of inflorescences in TB iris the following spring. Spring fertilization 
Table 6. Nitrogen (N) concentration, content, and allocation in tissues of container-grown 'Immortality' tall bearded iris. Plants were fertigated twice weekly with $0,5,10,15$, or $20 \mathrm{~mm} \mathrm{~N}$ from Mar. to Sept. 2012 and twice weekly with 0 or $10 \mathrm{~mm}{ }^{15} \mathrm{~N}$ from Mar. to May 2013 using a modified Hoagland's solution. Rhizomes were planted in Mar. 2012 and plants were harvested in May 2013.

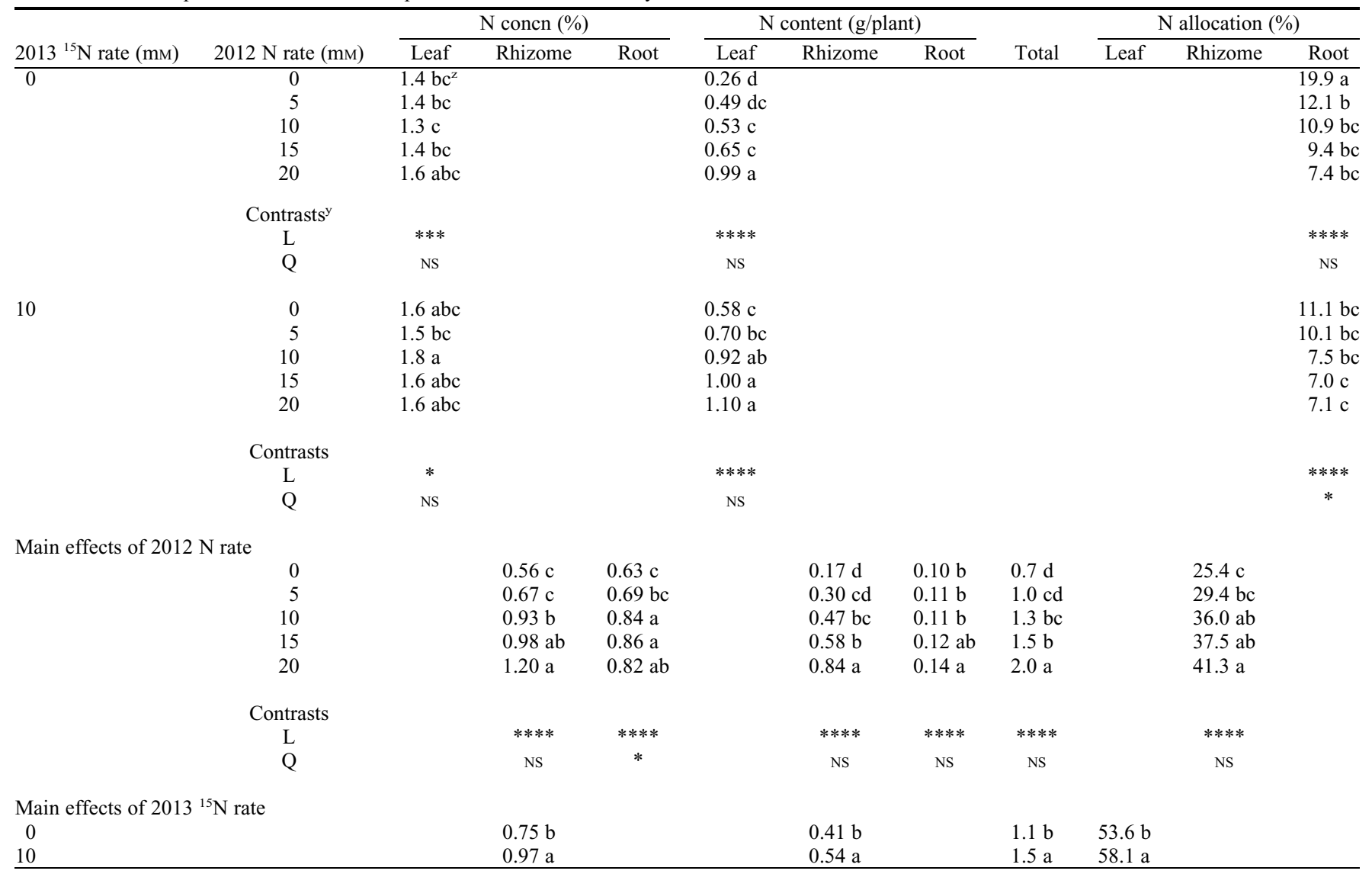

${ }^{\mathrm{z}}$ Means within a column followed by different letters denote significant differences (Tukey's honestly significant difference; $P \leq 0.05$ ).

${ }^{\mathrm{y}}$ Significant linear $(\mathrm{L})$ or quadratic $(\mathrm{Q})$ trends at not significant (NS) or $P \leq 0.05(*), 0.01(* *), 0.001(* * *), 0.0001(* * * *)$.

Table 7. Percentage of nitrogen (N) derived from ${ }^{15} \mathrm{NH}_{4}{ }^{15} \mathrm{NO}_{3}$ fertilizer (NDFF\%) of container-grown 'Immortality' tall bearded iris. Plants were fertigated twice weekly with $0,5,10,15$, or $20 \mathrm{~mm} \mathrm{~N}$ from Mar. to Sept. 2012 and twice weekly with 0 or $10 \mathrm{~mm}{ }^{15} \mathrm{~N}$ from Mar. to May 2013 using a modified Hoagland's solution. Rhizomes were planted in Mar. 2012 and plants were harvested in May 2013.

\begin{tabular}{|c|c|c|c|c|c|c|c|c|c|}
\hline \multirow[b]{2}{*}{$2012 \mathrm{~N}$ rate $(\mathrm{mM})$} & \multicolumn{3}{|c|}{ NDFF $\%$} & \multicolumn{3}{|c|}{ Amount of recovered ${ }^{15} \mathrm{~N}(\mathrm{~g})$} & \multicolumn{3}{|c|}{${ }^{15} \mathrm{~N}$ Allocation (\%) } \\
\hline & Leaf & Rhizome & Root & Leaf & Rhizome & Root & Leaf & Rhizome & Root \\
\hline 0 & $55.4 \mathrm{a}^{\mathrm{z}}$ & $36.4 \mathrm{a}$ & $42.7 \mathrm{a}$ & 0.32 & 0.08 & 0.04 & 72.2 & 18.1 & 9.7 \\
\hline 5 & $37.9 \mathrm{~b}$ & $32.3 \mathrm{ab}$ & $34.6 \mathrm{ab}$ & 0.26 & 0.11 & 0.04 & 64.3 & 26.1 & 9.6 \\
\hline 10 & $30.6 \mathrm{bc}$ & $23.5 \mathrm{abc}$ & $28.2 \mathrm{bc}$ & 0.27 & 0.12 & 0.03 & 63.4 & 29.0 & 7.6 \\
\hline 15 & $31.5 \mathrm{bc}$ & $24.3 \mathrm{bc}$ & $31.5 \mathrm{bc}$ & 0.31 & 0.17 & 0.04 & 59.7 & 31.9 & 8.4 \\
\hline 20 & $17.1 \mathrm{c}$ & $14.6 \mathrm{c}$ & $22.5 \mathrm{c}$ & 0.22 & 0.12 & 0.03 & 56.8 & 34.3 & 8.9 \\
\hline \multicolumn{10}{|l|}{ Contrasts $^{y}$} \\
\hline $\mathrm{L}$ & $* * * *$ & $* * * *$ & $* * * *$ & NS & * & * & ** & NS & ** \\
\hline $\mathrm{Q}$ & NS & NS & NS & NS & NS & NS & NS & NS & NS \\
\hline
\end{tabular}

${ }^{\mathrm{z}}$ Means within a column followed by different letters denote significant differences (Tukey's honestly significant difference; $P \leq 0.05)$.

${ }^{\mathrm{y}}$ Significant linear (L) or quadratic (Q) trends at not significant (NS) or $P \leq 0.05(*), 0.01(* *), 0.001(* * *)$, $0.0001(* * *)$.

did not stimulate new growth that matured soon enough to initiate flowers and bloom the same year. Applying $10 \mathrm{~mm}{ }^{15} \mathrm{~N}$ to plants receiving $0 \mathrm{~mm} N$ in 2012 resulted in some flowers. Plants receiving $0 \mathrm{~mm} \mathrm{~N}$ from 2012 fertigation may have initiated flower meristems in 2012 and $\mathrm{N}$ applied in 2013 may have supplied the necessary $\mathrm{N}$ nutrition to support flower development for blooming in 2013.

The number of inflorescence at first bloom in 2013 was less than that in 2012.
In Mar. 2013, plants in each pot had more than six fans and the rhizomes may not have gained sufficient size or maturity to flower in Spring 2013. This is supported by the rhizome maturity study of Craver and Harkess (2012), which showed that floral initiation was related to rhizome caliper and larger rhizomes were more likely to initiate flowers. Similar results were observed with gladiolus, which had the greatest flowering rate using largest corm size and highest $\mathrm{N}$ rate.
Compared with plant tissue $\mathrm{N}$ concentration in Dec. 2012, N concentration in May 2013 declined in all tissues. Increased dry matter production can cause a dilution in tissue $\mathrm{N}$ concentration. For rhizomes, the greatest $\mathrm{N}$ concentration in May 2013 was $\approx 3$-fold less than N concentration in Dec. 2012. Considering rhizomes serve as storage organs in $\mathrm{TB}$ iris, this reduction suggests translocation of $\mathrm{N}$ from rhizomes to new growing tissues. In addition, a greater proportion of $\mathrm{N}$ was allocated to rhizomes, but in May 2013 it was allocated to leaves, with leaves being a stronger sink for $\mathrm{N}$ than rhizomes and roots. This result also supports $\mathrm{N}$ stored in rhizomes being remobilized to the leaves during spring growth.

In Spring 2013, the proportion of ${ }^{15} \mathrm{~N}$ in leaves, roots, and rhizomes derived from ${ }^{15} \mathrm{NH}_{4}{ }^{15} \mathrm{NO}_{3}$ fertilizer (NDFF\%) decreased as the $2012 \mathrm{~N}$ application rate increased. Considering greater $2012 \mathrm{~N}$ rates, increased reserve $\mathrm{N}$ (N content in Dec. 2012) and the amount of ${ }^{15} \mathrm{~N}$ recovered in 2013 were similar across the $2012 \mathrm{~N}$ rate, the proportion of ${ }^{15} \mathrm{~N}$ in plant tissues was reduced by increasing amount of reserve $\mathrm{N}$ from the previous year.

In this study, the amount of ${ }^{15} \mathrm{~N}$ accumulation in 2013 in leaves and total plant tissue was unaffected by $2012 \mathrm{~N}$ rate. With tulip, greater $\mathrm{N}$ supplies increased $\mathrm{N}$ concentration 
of the mother bulb and decreased subsequent $\mathrm{N}$ uptake (Amano, 1986). Greater $2012 \mathrm{~N}$ rates led to larger plants in Mar. 2013, which required a greater amount of $\mathrm{N}$ to support growth. Even with more reserve $\mathrm{N}$ from the previous year, those plants treated with greater $\mathrm{N}$ rates took up a similar amount of $\mathrm{N}$ as those plants treated with lower $\mathrm{N}$ rates in 2012.

In summary, increasing $2012 \mathrm{~N}$ rate increased the number of inflorescence stems, plant dry weight, and plant $\mathrm{N}$ content of $\mathrm{TB}$ iris 'Immortality' in 2012. Application of N during the spring of the following growing season promoted leaf growth, and had only a slight influence on flowering in Spring 2013. Nitrogen was predominantly allocated to rhizomes in Dec. 2012 and to leaves in May 2013. Amount of N uptake from 2013 ${ }^{15} \mathrm{~N}$ was unaffected by $2012 \mathrm{~N}$ rate. As $\mathrm{N}$ supply in the previous year increased, the proportion of NDFF decreased due to a dilution effect by greater amount of reserve $\mathrm{N}$ from the previous year.

'Immortality' TB iris is capable of repeat blooming in a growing season; however, the second bloom was largely influenced by $\mathrm{N}$ fertilization rate in the year of flowering. Thus, a relatively high $\mathrm{N}$ rate is needed to produce a second bloom. Flowering of plants in the spring was more dependent on $\mathrm{N}$ applied and stored from the previous year than $\mathrm{N}$ applied in the spring. Higher $\mathrm{N}$ rates in the previous year are recommended to improve production of inflorescence stems the following spring.

\section{Literature Cited}

Amano, M. 1986. Influence of mother bulb nitrogen on subsequent nitrogen uptake in tulips. Acta Hort. 177:423-443.

Baba, A. and T. Ikarashi. 1967. Mineral nutrition of tulip flowering phase. I. Shokubutu Seiri 6:47-55.

Bi, G., C.F. Scagel, L. Cheng, S. Dong, and L.H. Fuchigami. 2003. Spring growth of almond nursery trees depends upon nitrogen from both plant reserves and spring fertilizer application. J. Hort. Sci. Biotechnol. 78:853-858.

Bi, G., C.F. Scagel, L.H. Fuchigami, and R.P. Regan. 2007. Rate of nitrogen application during the growing season alters the response of container-grown rhododendron and azalea to foliar application of urea in the autumn. J. Hort. Sci. Biotechnol. 82:753-763.

Bichsel, R.G., T.W. Starman, and Y.T. Wang. 2008. Nitrogen, phosphorus, and potassium requirements for optimizing growth and flowering of the nobile dendrobium as a potted orchid. HortScience 43:328-332.

Chang, K.H., R.Y. Wu, G.P. Chang, T.F. Hsieh, and R.S. Chung. 2012. Effects of nitrogen concentration on growth and nutrient uptake of Anthurium andraeanum Lind. cultivated in coir under different seasonal conditions. HortScience 47:515-521.
Cheng, L., S. Dong, S. Guak, and L.H. Fuchigami. 2001. Effects of nitrogen fertigation on reserve nitrogen and carbohydrate status and regrowth performance of pear nursery plants. Acta Hort. 564:51-62.

Craver, J.K. and R.L. Harkess. 2012. Determining rhizome maturity in reblooming iris. HortScience 47:S14

Dong, S., L. Cheng, C.F. Scagel, and L.H. Fuchigami. 2004. Nitrogen mobilization, nitrogen uptake and growth of cuttings obtained from poplar stock plants grown in different $\mathrm{N}$ regimes and sprayed with urea in autumn. Tree Physiol. 24:355-359.

Gáborčík, N. 2003. Relationship between contents of chlorophyll $(\mathrm{a}+\mathrm{b})$ (SPAD values) and nitrogen of some temperate grasses. Photosynthetica 41:285-287.

Ghosh, M., D.K. Swain, M.K. Jha, and V.K. Tewari. 2013. Precision nitrogen management using chlorophyll meter for improving growth, productivity and $\mathrm{N}$ use efficiency of rice in subtropical climate. J. Agr. Sci. 5:253-266.

Hanley, N., R.L. Harkess, and M. Gu. 2008. Plant growth regulator and fertilizer effects on growth and flowering of re-blooming iris. HortScience 43:1176.

Hoagland, D.R. and D.I. Arnon. 1950. The waterculture method for growing plants without soil. Calif. Agr. Expt. Sta. Circ. 347:1-32.

Islam, M.S., M.S.U. Bhuiya, S. Rahmanand, and M.M. Hussain. 2009. Evaluation of SPAD and LCC based nitrogen management in rice (Oryza sativa L.). Bangladesh J. Agr. Res. 34:661-672.

Jordan, M.O., G. Vercambre, L. Gomez, and L. Pagès. 2013. The early spring $\mathrm{N}$ uptake of young peach trees (Prunus persica) is affected by past and current fertilizations and levels of $C$ and N stores. Tree Physiol. 34:61-72.

Khan, F.N., M.M. Rahman, A.J.M.S. Karim, and K.M. Hossain. 2012. Effects of nitrogen and potassium on growth and yield of gladiolus corms. Bangladesh J. Agr. Res. 37:607-616.

Khuankaew, T., S. Ruamrungsri, S. Ito, T. Sato, N Ohtake, K. Sueyoshi, and T. Ohyama. 2010. Assimilation and translocation of nitrogen and carbon in Curcuma alismatifolia Gagnep. Plant Biol. 12:414-423.

Lea-Cox, J.D., J.P. Syvertsen, and D.A. Graetz. 2001. Springtime ${ }^{15}$ nitrogen uptake, partitioning, and leaching losses from young bearing Citrus tree of differing nitrogen status. J. Amer. Soc. Hort. Sci. 126:242-251.

Lemaire, G. and P. Millard. 1999. An ecophysiological approach to modelling resource fluxes in competing plants. J. Expt. Bot. 50:15-28.

Lin, Y., F. Guo, J. Luo, J. Sun, and Y. Zhang. 2011. Effect of different $\mathrm{N}$ rates on nutrient accumulation and nitrogen use efficiency in rainfed land Lanzhou lily. Acta Prataculturae Sinica 20:101-108.

Lockatell, M. and G.D. Spoon. 2011. Culturally speaking: The secret of reblooming irises. Bul. Amer. Iris Soc. 92(3):32-33.

Marschner, P. 2012. Mineral nutrition of higher plants. 3rd ed. Academic Press, London. UK

Millard, P. 1995. Internal cycling of nitrogen in trees. Acta Hort. 383:3-13.
Morris, J. 2011. How to plant and grow bearded iris. 17 Nov. 2014. <http://www.irises.org/About Irises/Cultural\%20Information/Grow_Bearded. html>.

Netton, A.T., E. Campostrini, J.G. Oliveira, and R.E. Bressan-Smith. 2005. Photosynthetic pigments, nitrogen, chlorophyll a fluorescence and SPAD-502 readings in coffee leaves. Sci. Hort. 104:199-209.

Ohtake, N., S. Ruamrungsri, S. Ito, K. Sueyoshi, T. Ohyama, and P. Apavatjrut. 2006. Effect of nitrogen supply on nitrogen and carbohydrate constituent accumulation in rhizomes and storage roots of Curcuma alismatifolia Gagnep. Soil Sci. Plant Nutr. 52:711-716.

Ohyama, T., T. Ikarashi, and A. Baba. 1985 Nitrogen accumulation of tulip (Tulipa gesneriana). Soil Sci. Plant Nutr. 31:581-588.

Ohyama, T., T. Ikarashi, A. Obata, and A. Baba. 1988. Role of nitrogen accumulated in tulip roots during winter season. Soil Sci. Plant Nutr. 34:341-350.

Roodbol, F., E. Louw, and J.G. Niederwieser. 2002. Effects of nutrient regime on bulb yield and plant quality of Lachenalia Jacq. (Hyacinthaceae). South African J. Plant Soil 19:23-26.

Ruamrungsri, S., W. Bumphenyoo, R. Sriwichai, and P. Apavatjrut. 2007. Effects of nitrogen, phosphorus and potassium deficiencies on growth and development of Globba rosae Gagnep. Kasetsart J. Nat. Sci. 41:72-83.

Ruamrungsri, S., N. Ohtake, K. Sueyoshi, C Suwanthada, T. Ohyama, and P. Apavatjrut. 2005. Effect of nitrogen and potassium on growth and development of Curcuma alismatifolia Gagnep. Acta Hort. 673:443-448.

Schuman, G.E., M.A. Stanley, and D. Knudsen 1973. Automated total nitrogen analysis of soil and plant samples. Proc. Soil Sci. Soc. Amer. $37: 480-481$.

Smith, M.A., G.C. Elliott, and M.P. Bridgen. 1998. Calcium and nitrogen fertilization of Alstroemeria for cut flower production. HortScience 33:55-59.

Syvertsen, J.P. and M.L. Smith, Jr. 1996. Nitrogen uptake efficiency and leaching losses from lysimeter-grown Citrus trees fertilized at three nitrogen rates. J. Amer. Soc. Hort. Sci. 121:57-62.

Yasumoto, S., K. Suzuki, M. Matsuzaki, S. Hiradate, K. Oose, H. Hirokane, and K. Okada. 2011. Effects of plant residue, root exudate and juvenile plants of rapeseed (Brassica napus L.) on the germination, growth, yield, and quality of subsequent crops in successive and rotational cropping systems. Plant Prod. Sci. 14:339-348.

Younis, A., M.A.P. Khan, and A. Riaz. 2009. Effect of different levels of nitrogen, phosphorus, and potash fertilizers on growth of Dahlia coccinea cv. decorative. Caderno de Pesquisa série. Biologia 18:8-14.

Zhu, Q., Y. Pan, and L. Zhao. 2012. The effects of $\mathrm{N}, \mathrm{P}, \mathrm{K}$, and $\mathrm{Ca}$ on plant growth and nutrient content of lily leaves. Acta Prataculturae Sinica $21: 274-284$. 